\title{
Cartas ao Imperador: os pedidos de perdão de réus escravos e a decisão de 17 de outubro de 1872
}

Letters to the Emperor: the requests for pardon by defendants' slaves and the decision of October 17, 1872.

DOI

http://dx.doi.org/10.1590/2236-463320161307

\section{Ricardo Figueiredo Pirola \\ Universidade Estadual de Campinas \\ - UNICAMP, São Paulo - SP, Brasil. \\ ricardopirola@yahoo.com}

\section{Resumo}

0 objetivo deste artigo é analisar a decisão do Imperador Dom Pedro II datada de 17 de outubro de 1872 de alforriar réus escravos que viessem a ser perdoados de uma sentença perpétua. Isto é, com essa decisão, os escravos que fossem contemplados com o perdão da pena de prisão ou de galés perpétuas não mais seriam obrigados a retornar ao domínio de seus antigos senhores, ficando plenamente livres. Mesmo não sendo desconhecida da bibliografia especializada, essa decisão de 1872 ainda tem sido pouco explorada. Assim, o objetivo deste artigo é analisar tanto os debates que antecederam a resolução do monarca, ocorridos no Ministério da Justiça e seção Justiça do Conselho de Estado, como ainda investigar o perfil dos réus libertados, a frequência com que tais decisões ocorriam e seu impacto no processo emancipacionista. Também interessa analisar a relação da decisão de 17 de outubro de 1872 com a intensificação do envio de cartas de perdão de réus escravos ao Imperador nos anos subsequentes.

\begin{abstract}
The aim of this paper is to analyze the decision of Emperor Dom Pedro II dated from October 17, 1872, to manumit defendants' slaves who were forgiven of a life sentence. That is, with this decision, the slaves that were pardoned by the monarch of a life sentence in prison, no longer would be required to return to their masters control, they were fully free. While not complete unknown to researches of slavery, the 1872 decision has yet been little explored. The purpose of this paper is to analyze both the debate leading up to the resolution of the monarch in 1872, took place in the Ministry of Justice and the Justice section of the State Council, but also examines the profile of released defendants, the frequency with which slaves were pardoned by Dom Pedro II and the impact of these actions in the emancipation process. Also it is important to analyze the relationship between the decision of 1872 and the intensification of the process of sending forgiveness letters by slave defendants to the Emperor in subsequent years.
\end{abstract}

Palavras-chave

Escravidão; Emancipação; Poder Moderador; Réus Escravos.

Keywords

Slavery; Emancipation; Moderating Power; Defendants' slaves. 
1

CAROATÁ, José Prospero Jeová (org). Imperiais Resoluções tomadas sobre Consultas da Seção de Justiça do Conselho de Estado desde o ano de 1842 até hoje. Volume 2. Rio de Janeiro: B.L. Garnier Livreiro Editor, 1884, p. 1586. Ibidem, p. 1589

3

NABUCO, Joaquim. Um estadista do Império: sua vida, suas opiniões, sua época. Volume 3. Rio de Janeiro: Garnier Livreiro e Editor, 1897, p. 468.

4

CHALHOUB, Sidney. Visões da liberdade: uma história das últimas décadas da escravidão na Corte. São Paulo: Companhia das Letras, 1990, p. 175-182. AZEVEDO, Elciene. 0 direito dos escravos: lutas juridicas e abolicionismo na província de São Paulo. Campinas: Editora da Unicamp, 2010, p. 57-85.

5

Para um estudo das práticas de perdões no periodo anterior a independência, ver: WOOD, Russell. Vassalo e soberano: apelos extrajudiciais de africanos e de indivíduos de origem africana na América portuguesa. In: SILVA, Maria Beatriz Nizza da (org). Cultura portuguesa na Terra de Santa Cruz. Lisboa, Estampa, 1995, p. 230-231.
Nos primeiros meses de 1872, o Diretor da Casa de Correção da Corte enviou um ofício ao Ministro da Justiça perguntando qual procedimento deveria adotar diante dos casos de escravos que eram perdoados pelo Poder Moderador da pena de galés ou de prisão perpétua. 0 diretor queria saber se os perdoados deveriam retornar ao domínio de seus senhores ou se estariam definitivamente livres. ${ }^{1}$ A Constituição Imperial de 1824 garantia ao monarca a atribuição de comutar ou perdoar as penas impostas pelo Judiciário aos habitantes do Brasil. Tanto Dom Pedro I como seu filho Dom Pedro II exerceram essa atribuição, geralmente comutando a pena de réus condenados à morte na de galés ou prisão perpétua com trabalho. Chegaram também a exercer o direito de perdoar as penas de condenados, especialmente de homens livres. Mas a pergunta do diretor da Casa de Correção mostrava que no começo da década de 1870 era a situação dos escravos que gerava dúvidas sobre os procedimentos a serem adotados. A resposta não tardou muito a chegar. Depois de o monarca ouvir os pareceristas do ministério da Justiça e da seção Justiça do Conselho de Estado, em 17 de outubro de 1872, a conclusão foi a de que "o direito do senhor sobre o escravo desaparece pelo fato da condenação definitiva", como no caso das sentenças de galés ou prisão perpétua. Assim, "uma vez perdoado [o cativo] não pode voltar à escravidão, visto que em seu benefício e não no interesse do antigo senhor cessa por virtude da Graça (sic) a perpetuidade da pena"2.

A bibliografia tem se voltado para essa decisão do Imperador em 1872, tanto para caracterizá-la como mais um exemplo do avanço do processo emancipacionista no Brasil, como ainda para ressaltar os desdobramentos dessa disposição nos movimentos de rebeldia dos cativos. Joaquim Nabuco, por exemplo, ao comentar a atuação de seu pai, Nabuco de Araújo, no Conselho de Estado, destaca a decisão de 1872 como uma medida do governo imperial, logo após a criação da lei de 28 de setembro de 1871 (a lei do ventre livre), de querer fazer progredir o processo emancipacionista no Brasil, ampliando os meios de acesso à liberdade. 0 autor fala da medida para exemplificar as "tendências humanitárias" e o caráter emancipacionista de Nabuco de Araújo, pois fora ele quem elaborara parecer favorável à libertação dos cativos e que acabou servindo de base para a decisão do monarca ${ }^{3}$. Já Sidney Chalhoub e Elciene Azevedo, por sua vez, associaram a decisão de outubro de 1872 à estratégia dos escravos de recorrerem à polícia depois de cometerem um crime. ${ }^{4}$ De acordo com esses autores, a garantia de que não retornariam à casa de seus senhores, depois de serem perdoados pelo monarca, teve como consequência ampliar a percepção dos cativos a respeito das instituições imperiais como arenas favoráveis de luta contra a escravidão.

Ao chamar a atenção para a decisão de 17 de outubro de 1872 não pretendo discordar das considerações levantadas até agora pela bibliografia. De fato, a resposta do governo Imperial à pergunta do Diretor da Casa de Correção me parece indissociável da conjuntura emancipacionista, da mesma forma que os seus desdobramentos parecem ter mesmo empolgado muitos cativos na luta contra a escravidão. Contudo, existem outros elementos que ainda não têm sido devidamente considerados. É preciso conhecer meIhor quem eram os réus perdoados, com que frequência o Imperador concedia tal graça aos escravos e porque a dúvida aparece no começo dos anos 70 do século XIX, já que a prática de concessão de graça remete a primeira metade do oitocentos e mesmo a períodos anteriores ${ }^{5}$. Mostra-se importante ainda investigar as relações dessa medida com a intensificação do envio 
de pedidos de graça de réus escravos ao Poder Moderador, depois de 1872. Ao analisar a documentação do Ministério da Justiça e Conselho de Estado, intitulada Prisão, Anistia, Comutação de Penas e Prisão, Petição de Graça, do fundo GIFI, no Arquivo Nacional, me deparei com uma alta concentração de cartas de perdão de escravos datadas dos anos 70 e 80 do século XIX, com réus despachando seguidamente cartas ao monarca (por vezes, três ou quatro pedidos de graça) em um curto período de tempo. Assim, para tentar avançar nessas questões, começo este artigo destacando o debate suscitado pela questão levantada pelo Diretor da Casa de Correção, passo depois para a análise sobre o perfil dos réus e, por fim, analiso alguns pedidos de graça de réus escravos.

\section{0 perdão Imperial em debate}

0 questionamento do diretor da Casa de Correção da Corte sobre a condição dos escravos perdoados pelo Imperador foi analisado inicialmente por um funcionário do Ministério da Justiça, Cunha Figueiredo, que apresentou sua decisão logo em 25 de abril de 1872. De fato, era praxe da burocracia Imperial, durante a década de 1870, que as dúvidas acerca de procedimentos jurídicos fossem primeiramente analisadas dentro do Ministério da Justiça, sendo consultado o Conselho de Estado apenas naqueles casos em que persistissem questionamentos sobre a melhor forma de resolver a questão. De acordo com Cunha Figueiredo, não existia na tradição jurídica brasileira baliza alguma que pudesse ajudar na resposta à questão postulada pelo Diretor da Casa de Correção, sendo necessário, portanto, recorrer ao direito romano, a fim de encontrar uma solução para o problema. Para Cunha Figueiredo, o direito romano fazia uma distinção entre os servos da pena e os escravos sentenciados perpetuamente, sendo que, no primeiro caso, o perdão da pena representava a liberdade total e irrestrita ao beneficiado, já em relação ao segundo, o fim do cumprimento da pena significava o retorno ao domínio do antigo senhor. Como no Brasil não existia a condição de "servos da pena", prossegue o relator, o perdão aos réus escravos deveria levar, portanto, ao retorno ao cativeiro. Dessa forma, tinham as autoridades imperiais a obrigação de fazer regressar os perdoados do Imperador aos seus senhores.

CAROATÁ, José Prospero Jeová (org). Op. Cit., p.1586-1587. Ministério da Justiça, A. Fleury. ${ }^{6}$

0 caso subiu à seção de Justiça do Conselho de Estado, ganhando a relatoria de José Thomas Nabuco de Araújo. 0 conselheiro relator discordou dos funcionários do Ministério da Justiça e apresentou parecer favorável à libertação dos escravos sentenciados a pena de galés ou prisão perpétua que viessem a ser perdoados pelo monarca. Para ele, o benefício da graça imperial, nesses casos, voltava-se exclusivamente para o sentenciado, nunca em proveito do senhor.

\footnotetext{
A contingência única que pode fazer cessar essa pena perpétua é o perdão conferido pelo Poder Moderador. Mas o perdão é uma graça, é um favor. E no caso sujeito é mais; é um dever, que se funda na regeneração moral presumida pela conduta do condenado, durante o longo tempo do sofrimento da pena. Assim que, não pode a graça, sem absurdo, ter o efeito odioso de restituir à escravidão aquele a quem foi concedida. Se tal efeito a graça pudesse ter, não deveria ser concedida sem concederse também ao condenado a escolha entre ela [e] a continuação da pena, porque esta
} 
Ibidem, p. 1587

Ibidem, p.1587-1588.

bem pode ser para ele menos repugnante que a escravidão [...] A liberdade é aqui um fato jurídico, consequência necessária da graça, que fez cessar a perpetuidade da pena, não no interesse do senhor, mas só no interesse e como recompensa do condenado [...] A Secretaria cita, para fundar a sua opinião, a Lei de Justiniano, que acabou [com] a servidão da pena. 0 conselheiro relator entende, porém, que esta citação é mal aplicada, se não contraproducente. $1^{\circ}$. Porque a questão aqui não é a de servidão de pena, que compreende livres e escravos, mas da perpetuidade da pena, a qual exclui a possibilidade do domínio do senhor, e importa a perda do escravo. $2^{\circ}$. Porque não é licito aplicar a bem da escravidão e para a escravidão uma Lei toda destinada à Liberdade. 0 Conselheiro Relator pede licença a Vossa Majestade Imperial, para repetir as palavras de Justiniano, explicando essa Lei (Novella 22, Cap. 8): 'Bem longe de querer mudar o estado livre em condição servil, nós há muito tempo nos esforçamos em restituir os escravos à liberdade.?

Ao apresentar seu parecer aos dois outros membros da seção de Justiça do Conselho de Estado, Nabuco de Araújo enfrentou a oposição do Barão de Três Barras. Segundo o Barão, a solução proposta por Nabuco transformaria em estado "deplorável a sorte e posição dos senhores e suas famílias, cuja segurança ficaria inteiramente dependente da boa indole dos seus escravos". Se é verdade, pois, que nada é mais "repugnante que a escravidão", comentava o Barão, e se além disso se oferece a "expectativa de liberdade pelo perdão da pena", a própria existência dos senhores se transformaria em um "favor que os bons escravos Ihe prestariam". Em outras palavras, a liberdade advinda do perdão da pena representaria um incentivo à rebelião. Ao mesmo tempo, porém, em que expressava temores com a proposta de Nabuco, o Barão argumentava que não lhe parecia certo fazer o réu perdoado voltar ao domínio de seu senhor, como sugeriram os pareceristas do Ministério da Justiça. Ele temia que o senhor e sua família poderiam voltar a se transformar em vítimas da ação dos escravos saído da prisão ou das galés, pelo fato de o cativo ter ficado longo tempo fora do domínio senhorial, perdendo-se assim os "vínculos necessários de submissão". Como solução para o imbróglio jurídico, o Barão propunha que os escravos perdoados da pena passassem a pertencer ao Estado. ${ }^{8}$

Já Francisco de Paulo de Sayão Lobato, também conselheiro da seção de Justiça, argumentou em defesa da liberdade dos réus perdoados. Para Sayão Lobato, a partir do momento em que era imposta ao escravo uma pena perpétua, juridicamente o proprietário perdia qualquer direito de posse ou domínio, sendo que tal direito não poderia jamais ser restituído "por falta de disposição competente" e ainda por ser um "desacato" ao "Supremo Poder". Nabuco de Araújo voltou ainda a se pronunciar a respeito desse debate, destacando que a proposta do Barão de transformar os perdoados em escravos da nação não era executável, já que, pela lei de 28 de setembro de 1871, ficaram livres todos os cativos de propriedade do Estado Imperial. Em 17 de Outubro, Dom Pedro II deu a palavra final sobre a questão: concordou com Nabuco de Araújo e Sayão Lobato. Ficavam livres, portanto, os escravos perdoados por graça do Poder Moderador, sem ter que voltar ao antigo senhor.

0 debate suscitado pelo Diretor da Casa de Correção sobre o destino dos réus perdoados pelo monarca revela que os assuntos ligados à emancipação dos escravos geravam forte polêmica, especialmente quando se tratava da alforria à revelia da vontade senhorial. No caso em questão, destacam-se tanto as preocupações com a segurança da família senhorial (e consequentemente da ordem pública do Império), quanto os argumentos em defesa do direito à liberdade e da crítica à escravidão. É curioso ainda notar 
9

Registro de decretos do Poder Moderador. IJ3 5*, Série Justiça, Arquivo Nacional (AN).

10 Perdões, Comutações. IJ3 9*, Série Justiça, AN.

11

GERSON, Brasil. A escravidão no Império. Rio de Janeiro: Pallas, 1975, p. 142-154.

12

Registro de decretos do Poder Moderador. IJ3 5*, Série Justiça, AN. João Luís Ribeiro no livro intitulado No meio das galinhas as baratas não têm razão faz uso da fonte IJ $3-5^{*}$ para se referir à questão das comutações de penas de livres e escravos. Ribeiro registra 138 comutações, sendo 98 casos de escravos e 39 de livres (de fato, a soma de 98 mais 39 resulta em 137 - há algum erro na composição dos dados de Ribeiro). Além disso, ao olhar apenas os casos envolvendo escravos encontrei 0 número de 106 réus que foram beneficiados por algum tipo de graça Imperial, ante aos 98 de Ribeiro. A diferença de dados, nesse caso, parece se relacionar com o fato de Ribeiro se concentrar apenas nos registros de réus que estavam condenados a morte, enquanto que eu abarquei todos os casos de escravos condenados (incluindo os condenados a morte ou ainda a penas menores). De qualquer forma, ao mencionar a fonte IJ3 $5^{*}$, Ribeiro não apesenta dados ou faz qualquer análise sobre os cativos que tiveram suas penas perdoadas pelo Imperador. Cf. RIBEIRO, João Luiz. No meio das galinhas, as baratas não têm razão: a lei de 10 de junho de 1835, os escravos e a pena de morte no Império do Brasil (1822-1889), Rio de Janeiro: Renovar, 2005, p. 254. os usos do direito romano, expresso nas interpretações opostas apresentadas por Cunha Figueiredo e Nabuco de Araújo. Mais do que uma discussão estritamente legalista sobre o direito romano, o debate exemplifica o caráter político das argumentações jurídicas em torno da escravidão, nas décadas finais do século XIX. Diante do impasse provocado pelas divergentes opiniões, sobressai a decisão do monarca, que ficou com a solução favorável à libertação dos cativos. 0 contexto emancipacionista do final do século XIX, do qual o Imperador era tanto parte como um dos seus incentivadores, foi o fiel da balança para o imbróglio levantado pelo Diretor da Casa de Correção. De fato, os próprios termos com que Nabuco de Araújo finalizou seu parecer, apresentando uma citação de Justiniano ("Bem longe de querer mudar o estado livre em condição servil, nós há muito tempo nos esforçamos em restituir os escravos à liberdade"), expressam bem o momento de crítica ao sistema escravista e a tendência em se favorecer a emancipação dos cativos.

Mas se considerações em torno do contexto emancipacionista ajudam a explicar o debate e a decisão de outubro de 1872, análises sobre o impacto dessa medida para a libertação efetiva dos escravos e o perfil dos agraciados pela decisão Imperial precisam ser melhor explorados. Assim, para avançar na compreensão dessas indagações focalizo duas séries documentais diferentes. Uma delas é o livro de registro de decretos do Poder Moderador para o período de 3 de março de 1854 até 19 de setembro de $1863^{9}$. Esse livro foi criado para registrar todos os decretos emitidos pelo chamado quarto poder, incluindo aí os casos de comutação e perdão de penas. Já a outra é o livro de registro da correspondência oficial do Ministro da Justiça com os demais membros da burocracia imperial (presidentes de província, juízes, parlamentares), compreendendo o período de 14 de abril de 1874 até 17 de dezembro de $1879^{10}$. De fato, as decisões do Poder Moderador eram despachadas pelo Ministro da Justiça para as diversas instâncias burocráticas para entrar em vigor, ficando registradas no livro de correspondência do ministério. Acrescento também à discussão os dados encontrados por Brasil Gerson em pesquisa nos jornais cariocas, entre os anos de 1850 até 1875 , sobre os réus perdoados. ${ }^{11}$ Não consegui informações sobre os réus perdoados para a primeira metade do século XIX, nem para a década de 1880, contudo, os dois livros de registros da burocracia imperial e os dados de Brasil Gerson nos ajudam a identificar algumas tendências no que se referem à quantidade e 0 perfil dos agraciados entre 1850 e 1870, possibilitando a construção de um quadro de possibilidades para as outras décadas.

No que se refere ao periodo entre março de 1854 e setembro de 1863 , identifiquei 106 réus escravos que foram beneficiados por algum tipo de graça imperial. ${ }^{11}$ Desse total, apenas $6(5,6 \%)$ deles alcançaram o perdão completo da pena. A grande maioria, 97 (91,5\%) foi beneficiada com a comutação da pena de morte em galés perpétuas ou prisão perpétua. Dois réus escravos $(1,8 \%)$ alcançaram a comutação da pena inicial para a de 20 anos de prisão e $1(0,9 \%)$ deles conseguiu comutar a sentença de primeira instância para seis anos de prisão. Tais dados deixam claro que o número de réus escravos que alcançavam o perdão completo de suas penas era muito reduzido, não chegando nem mesmo a 1 caso por ano $(0,66)$. Não consigo precisar o quanto tal fonte pode ter sub-registrado o número de ocorrências - imaginando, por exemplo, que o funcionário responsável por tal tarefa não fosse dos mais meticulosos com sua função. Contudo, a julgar pelos números encontrados por outros tipos de fontes documentais, o mais certo é que 0 monarca fosse bastante econômico na concessão do perdão real aos presos 
13

Perdões, Comutações. IJ3 9*, Série Justiça, AN. escravos.

Para o período de abril de 1874 até dezembro de 1879, o livro de registro da correspondência do Ministro da Justiça lista 117 réus escravos beneficiados pela graça imperial. ${ }^{13}$ Desse total, 13 deles $(11,1 \%)$ alcançaram o perdão completo da pena. A grande maioria, contudo, continuou sendo contemplada com a comutação da pena de morte em galés ou prisão perpétua, 97 réus (82,9\%). Outros 7 (5,9\%) escravos conseguiram penas menores que a perpétua (3 deles tiveram a sentença convertida em 20 anos de prisão com trabalho, 2 em 12 anos de prisão com trabalho, 1 em 1 ano de prisão com trabalho e 1 em seis meses de prisão com trabalho). Finalmente, apenas dois escravos, durante todo esse período, não obtiveram clemência alguma do monarca, sendo executados em praça pública. De acordo com essa documentação, o último réu escravo enforcado no país, por força de sentença judicial, foi o escravo Francisco na cidade de Pilar, Alagoas, em 1876.

Ao compararmos os resultados do livro de decretos do Poder Moderador (1854-1863) com o livro de registro da correspondência do Ministro da Justiça (1874-1879), é possível identificar um aumento significativo no número de perdões concedidos pelo monarca: no primeiro caso, eles representavam 5,6\% das graças imperiais (média de 0,66 réus por ano), já no segundo o número subiu para 11,1\% (média 2,6 casos por ano). Outra diferença importante é o crescimento do número de réus que conseguiram a comutação da pena inicial para sentenças menores que a perpétua, a porcentagem variou de $2,8 \%$ para o primeiro período para 5,9\% no segundo. Em todo caso, no que se refere aos réus escravos, o exercício das atribuições do Poder Moderador, no Brasil Imperial, se concentrou fortemente na comutação das penas de morte em galés ou prisão perpétua.

Os dados encontrados nesses dois livros podem ser analisados ainda em relação ao levantamento feito por Brasil Gerson a partir dos periódicos Jornal do Comércio e Diário Oficial, para o período de 1850 até 1875. De acordo com Gerson, foi possível identificar nesses jornais 195 casos de réus inicialmente condenados à morte que conseguiram algum tipo de graça do Poder Moderador. Suas análises indicam que 156 (80\%) réus escravos tiveram suas sentenças convertidas em galés ou prisão perpétua e cinco $(2,5 \%)$ em penas menores que a perpétua. Já o total de perdoados alcançou o número de 34 escravos $(17,4 \%)$. No que se refere a esses últimos, Gerson destacou ainda que 11 réus foram perdoados entre 1850-1870 e 23 deles no período de 1871-1875. ${ }^{14}$ Assim, os dados de Gerson confirmam duas conclusões fundamentais que chegamos com nossa pesquisa: primeiro, que a atuação do Poder Moderador se voltou especialmente para a comutação de penas capitais (substituindo-as pelas galés ou prisão perpétua); segundo, que houve um aumento considerável no número de escravos perdoados, especialmente a partir da década de 1870.

De fato, a grande diferença dos dados de Gerson com os levantamentos que produzi a partir dos livros de registro se refere à velocidade desse crescimento nos anos 70 do século XIX. Os dados de Gerson apontam que, entre 1850 e 1870, a média anual de perdões foi de 0,55; já entre 1871-1875 a média teria passado para 5,75 casos. Para os primeiros 20 anos da amostra de Gerson, a média anual de casos de perdão se aproxima do número que encontrei entre 1854-1863, 0,66 réus. A discrepância maior se refere ao aumento da década de 1870 que, ainda segundo Gerson, teria elevado o número de réus perdoados para quase 6 escravos por ano, enquanto os meus dados indicam menos de 3 (considerando aqui o livro de correspondência 
Registro de decretos do Poder Moderador. IJ3 5*, Série Justiça, AN.

16

Sobre a lei de 10 de junho de 1835, Ver: PINAUD, João Luiz Duboc. Senhor, escravo e direito: interpretação semântico-política In: ; ANDRADE, Carlos Otavio de; NEME,

Salete. Insurreição negra e justiça. Rio de Janeiro: Editora Expressão e Cultura, 1987; RIBEIRO, João Luiz. Op. Cit., p. 52-70; PIROLA, Ricardo F. Escravos e rebeldes nos tribunais do Império: uma história social da lei de 10 de junho de 1835, Rio de Janeiro: Arquivo Nacional, 2015 do Ministro da Justiça entre os anos de 1874-1879). É possivel dizer que essa diferença esteja ligada aos anos distintos analisados, isto é, na primeira metade da década de 1870 (estudada por Gerson) o número de perdões, de fato, teria disparado, saindo de uma média anual de menos de um caso para quase 6 e depois, na segunda metade dessa década (segundo meu levantamento), caiu para perto de 3 . Teríamos, nesse sentido, duas bruscas variações em dez anos.

0 grande problema com essa interpretação é encontrar uma justificativa consistente que seja capaz de explicar duas mudanças tão acentuadas na política Imperial em apenas uma década. Pelas discussões que acompanhei no Conselho de Estado e no Ministério da Justiça nada indicaria alterações tão significativas nos rumos da política de perdões. 0 mais certo, portanto, é que as diferenças de dados localizados por Gerson e pela minha pesquisa se refiram ao próprio formato das fontes estudas. Já destaquei anteriormente que as minhas amostras eventualmente poderiam apresentar problemas de sub-representação (por falta de anotações sistemáticas na época), mas é possivel também que os números de Gerson tenham sido inflacionados, ao ser feita a compilação das informações de dois diferentes jornais (pode ser, por exemplo, que um mesmo réu tenha sido contado mais de uma vez).

De qualquer forma, o que esses dados revelam é que quantitativamente o número de réus perdoados era pequeno (especialmente em comparação com os números de comutações de penas capitais para galés ou prisão perpétua). Na melhor das hipóteses, não chegava a 6 casos por ano, já, no pior cenário, não alcançava a 3 . É difícil dizer o que teria ocorrido na década de 1880, mas a julgar pelas respostas aos repetidos pedidos de graça nesse periodo, que analiso com mais detalhes logo a frente, o monarca não alterou significativamente sua política de perdões, fazendo com que o número de beneficiados talvez continuasse entre 3 e 6 casos anuais.

Uma questão, porém, ainda se impõe. Quem eram, afinal, os réus escravos beneficiados pelo perdão real? Uma maneira de responder a esta pergunta, com a documentação que levantamos, é analisar qual foi a pena aplicada pelos tribunais de primeira instância. Assim, entre 1854-1863, do total de 6 perdoados, identifiquei que dois deles foram condenados a 8 anos de galés, 1 a 12 anos de prisão com trabalho e somente 1 recebeu como pena inicial a sentença de galés perpétuas (no caso dos outros dois não foram fornecidos tais dados). ${ }^{15}$ Isso quer dizer que ao longo do período abordado pelo livro de decretos do Poder Moderador nenhum dos escravos perdoados havia sido condenado, inicialmente, a morte e, muito provavelmente, nenhum deles foi sentenciado pela lei de 10 de junho de 1835 (a severa lei do Império que punia com pena capital os crimes cometidos por escravos contra senhores, feitores e seus familiares) ${ }^{16}$. Seguindo a lógica de condenação das leis penais do Império, de que a pena crescia dependendo da gravidade do crime (e vice-versa, crimes menores, penas também menores), podemos afirmar então que os escravos perdoados eram aqueles que cometeram pequenos delitos como agressões (contra outros escravos ou homens livres que não eram ligados a família senhorial ou ao controle da produção agrícola), ou mesmo roubos. Isto é, muito possivelmente não se tratava de réus que cometeram assassinato ou insurreições, crimes em que dificilmente se escapava da pena capital.

Já no que se refere aos anos de 1874-1879 (tendo como fonte o livro de registro de correspondência do Ministro da Justiça), é possivel notar uma diferença fundamental no perfil dos perdoados, quando comparado com o 
17

Perdões, Comutações. IJ3 9*, Série Justiça, AN.

18

Esses condenados a pena capital alcançaram a primeira comutação em 1853, quando a sentença de morte foi convertida em galés perpétuas, e finalmente em 1875 foram perdoados das galés. período de $1853-1864 .{ }^{17}$ Dos 13 réus escravos que alcançaram a mais alta graça do Poder Moderador, nove deles haviam sido condenados inicialmente a galés perpétuas, dois a prisão perpétua e outros dois a pena de morte. ${ }^{18}$ Essa mudança no perfil dos escravos perdoados representava uma alteração significativa na própria categoria de "perdoáveis". Em outros termos, o Imperador passou a beneficiar com o perdão não mais os réus que haviam cometido pequenos crimes, mas sentenciados cuja pena inicial indicava um grave delito.

Nesse sentido, podemos destacar que mesmo não sendo 0 ato de perdoar uma novidade no começo da década de 1870, a política de concessões de graças, sob o comando de Dom Pedro II, passou por alterações significativas na segunda metade do oitocentos, que modificaram o cenário cotidiano enfrentado pelo diretor da Casa de Correção. Se nos anos 50 e 60, do século $\mathrm{XIX}$, os perdoados eram aqueles escravos que haviam cometido pequenos delitos e que permaneceram pouco tempo na prisão (talvez não existissem dúvidas nesses casos de que deveriam retornar ao cativeiro), nos anos 70 os beneficiados eram cativos que praticaram crimes mais graves e que chegaram a ser "perdidos para sempre" para seus senhores no momento da aplicação da sentença. Assim, o questionamento do diretor da Casa de Correção possivelmente refletia os primeiros impactos dessas alterações na política de perdões. A resposta dada pelos conselheiros do Imperador, já sabemos, favoreceu a liberdade.

\section{Cartas ao Imperador}

Imperial Senhor, a vida escabrosa por que tem passado a Suplicante durante 15 anos de privações do cárcere tem sido por demais suficiente para a reparação do mal causado; e o documento junto abona satisfatoriamente o comportamento da suplicante, no longo e árduo período de sua prisão. Senhor, condoei-vos da lamentável situação da infeliz que se acha condenada a terriveis tormentos perpetuamente sem que tivesse concorrido para isso provas robustas e exigidas pela lei; apenas o triste nome do cativeiro deu lugar a todo esse cortejo contido no sumário de culpa, formado à Suplicante o qual deu lugar a tão doloroso gravame que pesa sobre os dias da Suplicante. Senhor os atos de clemência do trono emanado perpetua o amor que [?] consagra a Vossa Majestade Imperial, o Povo Brasileiro; que terá sempre de orgulharse ao levantar-se pela Augusta Pessoa de Vossa Majestade Imperial na terra de Santa Cruz com pedestal entre a Justiça e Misericórdia [...]

Presídio de Fernando de Noronha, 27 de Março de 1876

A rogo de Josefa (escrava)

Antônio da Silva Campos"19

A citação acima é a transcrição de uma carta de perdão, escrita em nome da escrava Josefa ao Imperador Dom Pedro II, datada de 1876. Josefa foi condenada à morte em 14 de março de 1861, pelo júri da cidade de Parnaíba, na província do Piauí, pelo assassinato de seu senhor. A pena foi comutada na de prisão perpétua com trabalho no presidio da ilha de Fernando de Noronha. Desde janeiro de 1854 havia se tornado obrigatório a consulta ao Imperador de todos os casos de réus escravos condenados à pena capital. Antes dessa decisão, processos envolvendo o assassinato de senhores, 
20

Com o decreto de 1854 o curador ou advogado do cativo tinha até 7 dias após a publicação da sentença de morte pra recorrer em nome do réu, caso não o fizesse nesse prazo, a tarefa passava para a incumbência do juiz que presidiu 0 julgamento.

21

Sobre o processo que levou ao aumento das comutações a partir da década de 1860, ver: PIROLA, Ricardo F. Op. Cit., p.89-208.

Parecer do Ministério da Justiça. Maço 6H-49, GIFI, AN. como o de Josefa, não necessariamente subiam ao conhecimento do Poder Moderador; bastava uma autorização do presidente da província para que a sentença fosse executada. ${ }^{20} \mathrm{~A}$ partir do começo da década de 1860 , as comutações de pena capital se tornaram bastante frequentes - resultado tanto da publicação de uma série de decretos por parte do Poder Moderador, que reconheciam atenuantes na análise dos casos de réus escravos, como ainda da atuação do monarca, contrária a pena capital ${ }^{21}$. Foi justamente nesse contexto que Josefa conseguiu a comutação da pena de morte para a de prisão perpétua com trabalho. Já em 1876, a ré almejava a conquista de uma nova graça imperial que the garantisse agora o perdão completo da pena.

Os pedidos de graça dos escravos que cumpriam penas de prisão ou galés eram analisados inicialmente por funcionários do Ministério da Justiça e também pelo próprio Procurador da Coroa. Só depois iam parar nas mãos do monarca (a partir de 1870 o Procurador deixou de ser consultado). Cabia aos funcionários do Estado imperial elaborar pareceres que orientassem a decisão do monarca. No caso de Josefa, o seu pedido foi analisado por Próspero Jeová, que deu parecer negativo à solicitação da ré. Para Próspero Jeová, "os maus instintos" da escrava a fizeram cometer o "bárbaro atentado contra seu senhor, homem sexagenário, não havendo outro motivo para isso se não umas pancadas que lhe dera ele com uma estaca por não ter a suplicante feito o serviço que the fora designado e as quais não lhe causaram ferimento algum". Ainda segundo o funcionário do Ministério da Justiça, era necessário que a "má índole da escrava fosse severamente corrigida", sendo a concessão do perdão "um mal moral para ela e um incentivo poderoso a crimes desta ordem". A decisão de Próspero Jeová foi acompanhada pelo diretor geral da terceira seção, A. Fleury. Ao tomar conhecimento do caso, o Imperador também negou à Josefa o perdão da pena. ${ }^{22}$

Dois anos mais tarde, Josefa voltou a pressionar as autoridades imperais em busca de uma revisão de sua pena. Sua carta foi escrita agora por Liberalino Rodrigues Machado. Nesse novo pedido de perdão, Josefa abandonou o argumento de que não existiram "provas robustas" sobre sua culpa, como alegara anteriormente, para concentrar a sua defesa na questão do "longo tempo" que estava presa.

\begin{abstract}
A clemência do Augusto Trono de Vossa Majestade Imperial vem a misera Josefa, escrava condenada a prisão perpétua com trabalhos, por comutação do Poder Moderador, que houve por bem comutar a pena de morte imposta pelo júri da cidade de Parnaiba, da província do Piauí, em 14 de março de 1861, por crime de homicídio. Senhor! São passados longos anos que a suplicante foi acusada de um crime contra as leis do país, após a condenação do patíbulo. Vossa Majestade Imperial estendeu seu manto de misericórdia comutando-a na pena de prisão perpétua para este Presídio, onde ela suplicante, resignada tem espiado o crime que perpetrou, embora por ignorância, mas infelizmente é certo que há muitos anos houve um crime e que a infeliz jaz no jugo do cárcere arrependida e regenerada porque os longos anos de sofrimento são bastantes para mitigar os rigores da justiça e o coração paternal de Vossa Majestade Imperial jamais faltou a Clemência do Perdão que ela suplicante vem pedir hoje em nome de Deus, das augustas sereníssimas Princesas e de Vossa Majestade Imperial, pelo que
\end{abstract}

\section{E Receberá Mercê}

Presídio de Fernando de Noronha, 23 de Novembro de 1878 
23

Pedido de perdão, 23 de janeiro de 1878, Maço $6 \mathrm{H}-49$, GIFI, AN.

24

Parecer do Ministério da Justiça. Maço 6H-49, GIFI, AN.
Liberalino Rodrigues Machado ${ }^{23}$

0 pedido de perdão de Josefa foi novamente analisado por Próspero Jeová, o mesmo parecerista que já havia Ihe negado a solicitação dois anos antes. 0 funcionário do Ministério da Justiça voltou a destacar que a culpa da ré era "gravíssima", não sendo suficiente o "bom comportamento" apresentado por ela na prisão, nem os 16 anos e meio de pena para reabilitá-la. Concluía, em um curto parecer, que os "protestos de arrependimento e regeneração que Josefa apresenta" não bastavam para fundamentar um novo perdão. A posição de Próspero Jeová foi referendada pelo giretor geral, Figueiredo José. ${ }^{24} 0$ monarca, mais uma vez, seguiu os conselhos de seus parecerista, decidindo pela recusa do pedido da ré. É curioso notar nos dois pedidos de Josefa (e também em outras cartas de perdão das décadas de 1870 e 1880) a adoção de certo padrão na organização narrativa, que começava com a apresentação da condenação para logo em seguida destacar os argumentos fundamentais com que esperavam convencer o Imperador (a exemplo de erros no processo, falta de provas, longo tempo passado na prisão ou galés). Além disso, os peticionários são apresentados em posição sempre respeitosa ao monarca, "prostrados" ou "ajoelhados" diante do "trono" ou dos "pés do Imperador", ao se aproximarem metaforicamente do trono imperial em busca da graça. No caso de Josefa, o pedido carregou nos adjetivos que caracterizavam a submissão da ré ("mísera", "submissa", "infeliz").

Depois dessa segunda recusa, Josefa não mandou mais cartas ao Poder Moderador em busca do perdão da sua pena. No ano de 1888, entretanto, já abolida a escravidão, o seu caso foi novamente analisado pelos funcionários do Ministério da Justiça. Após o 13 de maio, o próprio monarca ordenou uma revisão geral dos processos de réus condenados pela lei de 10 de junho de 1835 (principal instrumento jurídico do Império na condenação dos réus escravos). Nessa nova revisão, os pareceristas do Ministério da Justiça consideraram Josefa agora digna do perdão imperial. No parecer dado em 1888, foi destacado que por não haver outras provas do crime, além da confissão da ré, e ainda por ter sido o mesmo cometido depois que lhe castigou o antigo senhor, "pode ser comutada a pena de prisão perpétua em prisão por 20 anos, mínimo do artigo 192 do Código Penal [assassinato com agravantes]. Havendo decorrido mais de 26 anos, a comutação importará o perdão". 0 decreto de libertação de Josefa foi publicado no dia 13 de maio de 1889, juntamente com diversos outros casos de réus que haviam sido condenados pela lei de 10 de junho de 1835 e que puderam finalmente comemorar as suas libertações.

Outro caso de réus escravos que cumpriam penas perpétuas e que passaram a pressionar sistematicamente pelo perdão da sentença é o dos escravos Bráulio, Benjamin, Moisés, Inácio e João, da vila de Nazareth, na Bahia. Os cinco escravos haviam sido condenados no ano de 1867 a pena de morte pelo assassinato de seu senhor Joaquim Porfírio de Sousa. ${ }^{25}$ Os cativos mataram a pauladas o senhor quando ele chegava em sua casa, na parte urbana de Nazareth. 0 corpo da vítima foi jogado na mesma noite no beco do Teatro, sendo encontrado logo no dia seguinte pela manhã. Presos os suspeitos, acabaram os cinco escravos sentenciados a pena capital. 0 próprio juiz de direito que presidiu o caso escreveu, em nome dos réus, uma solicitação de comutação da pena capital, como previa o decreto de 2 de 
Caso dos réus Bráulio, Benjamin, Moisés, Ignácio, Maço $5 \mathrm{H}-55$, GIFI, AN. janeiro de 1854. 0 resultado desse pedido foi terem conseguido os escravos a comutação da pena de morte para a de galés perpétuas, a ser cumprida no presídio de Fernando de Noronha. Começava então a saga dos escravos em alcançar uma redução da pena ou mesmo seu completo perdão.

0 primeiro dos cinco réus escravos a enviar ao monarca um novo pedido de graça foi Moisés, em 28 de junho de 1878. 0 documento foi escrito por Joaquim Alves dos Santos. Fazia então pouco mais de dez anos que Moisés cumpria pena de galés em Fernando de Noronha, sendo que sua principal alegação nessa carta era a de que não havia atuado diretamente na morte de seu senhor, desempenhando durante o crime apenas o papel de "cúmplice". 0 réu destacou ainda no documento os "atropelos" que enfrentava um escravo diante de um tribunal do júri e a impossibilidade de recorrer da sentença condenatória para "juizes letrados". Vejamos o que diz Moisés.

[...] Fosse como fosse, a punição era de esperar-se visto que, tanto autor como cúmplices, e não implicados no crime, deferido na Lei de 10 de Junho de 1835 que mandava executar-se um condenado a pena de morte, sem que os autos fossem vistos pelos Tribunais de juízes letrados, dando apenas o recurso, para o Poder Moderador, razão esta sem dúvida a que se deve, o não ter de lamentar-se, fatos desastrosos, como ainda hoje lamenta a França, no assassinato de seu Lesurques!... Ninguém há neste mundo que desconheça os atropelos em que se vê um infeliz escravo ante o júri, quando o crime lhe é atribuído por parte da justiça, por morte de senhor ou feitor, cuja circunstância e prevenção, tem até já dado lugar a abusos de se qualificarem os parceiros do réu feitores, para se impor ao infeliz as penas da Lei citada. ${ }^{26}$

Apelava, assim, Moisés para o "magnânimo e bondoso coração de Vossa Majestade Imperial" a fim de que o mesmo se dignasse "perdoar ou comutar a pena que lhe fora imposta". Despachada a carta para o Ministério da Justiça (parada obrigatória antes da documentação subir ao monarca), o caso foi analisado pelos funcionários da terceira seção, responsáveis então por esse tipo de pedido na década de 1870. Três foram os pareceristas que se manifestaram sobre a solicitação de Moisés. 0 primeiro deles, José Prospero Jeová, destacou que apesar da argumentação do réu em dizer que não contribuíra diretamente para o crime, os depoimentos no processo demonstravam que o peticionário fora sim "um dos assassinos de seu senhor, sendo ele quem apertava a corda [amarrada] ao pescoço da vítima". Além disso, Próspero Jeová destacou que o pedido de graça de Moisés não foi "instruído" corretamente, pois faltava a "informação do comandante do Presídio sobre o comportamento do peticionário no cumprimento da pena". Dessa forma, não considerava o réu digno de receber outra graça do Poder Moderador, que já o havia beneficiado uma vez, livrando-o da forca. Tal parecer foi seguido por Victorino de Barros que ressaltou ainda que independente de "novas informações" que pudessem ser enviadas a respeito do comportamento do réu, deveria a solicitação ser "indeferida". Já o diretor geral, apoiando as decisões de seus subordinados no ministério, assinou com um simples "concordo", sem acrescentar novas considerações. 0 caso subiu então ao monarca que também o indeferiu. Não fora daquela vez que se viu Moisés livre das correntes das galés. ${ }^{27}$

Essa primeira negativa em relação à solicitação não foi, contudo, suficiente para desanimar Moisés de tentar junto ao Imperador a revisão ou perdão de sua pena. Em 18 de abril de 1885, ele recorreu, mais uma vez, ao Poder Moderador, enviando novo pedido de graça. Nessa nova empreitada, 
Parecer do Ministério da Justiça. Réu Moisés. Maço $5 \mathrm{H}-55$, GIFI, AN.
Moisés foi ajudado por Gervasio Raimundo José dos Santos. 0 escravo Moisés insistiu, no documento ao monarca, que atuara como "cúmplice" naquele caso de assassinato. Destacou ainda que os verdadeiros "autores do crime" foram absolvidos, sendo condenados apenas aqueles que não tiveram quem se "interessasse" por suas causas. Dessa vez, ele mandou com o pedido de graça uma carta do comandante do Presídio de Fernando de Noronha, que atestava seu "bom comportamento". Fazia então cerca de 17 anos que Moisés cumpria pena de galés. Os pareceristas do Ministério da Justiça, contudo, negaram ao réu a possibilidade de perdão ou revisão de pena. De acordo os funcionários da terceira seção, a alegação de Moisés, de que desempenhara tão somente o papel de cúmplice no caso de assassinato de Joaquim Porfírio de Sousa era "falsa", não passava de uma tentativa de "iludir o Poder Moderador". Para eles, estava "provado pelos autos" a sua direta participação na morte de Joaquim Porfírio de Sousa. Seguindo o parecer do Ministério da Justiça, o Imperador também negou ao réu uma nova graça. ${ }^{28}$

Apesar dessas recusas, Moisés não se mostrava disposto a recuar de sua empreitada. Dois anos depois de sua última solicitação, enviou mais um pedido de graça. Juntou-se a ele agora, na luta pela liberdade, o seu parceiro de condenação, Inácio. De fato, a carta de Inácio foi despachada pouco tempo antes, em 3 de janeiro de 1887. Já a de Moisés foi enviada em 19 de fevereiro do mesmo ano. Novos defensores assinaram as cartas desses dois réus escravos. A de Inácio foi elaborada por João Evangelista Gomes de Castro, enquanto a de Moisés foi escrita por Sebastião Asteres Gadella. 0 argumento central das duas cartas foi o de que os réus já haviam cumprido mais de 20 anos de pena e estavam, portanto, "alquebrados pelos trabalhos, enfermos pelos rigores do cárcere, e arrependidos da culpa".

Apesar de terem sido escritas separadamente, e em datas diferentes, as duas cartas foram conjuntamente analisadas no Ministério da Justiça. Assim como haviam procedido das outras vezes, os funcionários da terceira seção voltaram a não recomendar a graça imperial a esses dois réus escravos. Os membros do Ministério da Justiça alegaram que os réus não eram dignos de terem suas penas mais uma vez modificadas, tendo em vista que já se beneficiaram com a comutação da pena de morte em galés. 0 diretor geral da terceira seção, Júlio de Albuquerque Barros, que das outras vezes se contentou em subscrever os pareceres de seus subordinados com a lacônica expressão "concordo", apresentou, contudo, um parecer um pouco mais extenso sobre o caso. 0 diretor geral anuiu que Moisés e Inácio não seriam merecedores da graça imperial, mas destacou, no mesmo documento, a possibilidade do perdão acontecer depois de encerrada a escravidão. 0 diretor geral recuperou, em seu parecer, um trecho do relatório do juiz de direito, produzido na época da condenação capital dos réus em 1867, para dizer que o crime dos escravos foi resultado do "desespero", diante da "crueldade do senhor". 0 diretor geral destacou também que era "voz pública", em Nazareth, que a vítima "já havia matado diversos [cativos] com açoites e atirado cinco de uma vez dentro de uma caldeira". Assim, concluiu: "penso que, ao menos, quando extinguir-se a escravidão, a súplica poderá ser atendida, sem quebra de justiça e de conveniências sociais". Datava o parecer de 6 de junho de $1887 . .^{29}$

Tais considerações do diretor geral representavam uma vitória importante para os réus de Nazareth na luta pela liberdade e ajudavam a evidenciar ainda o caráter político das decisões envolvendo os pedidos de graça. 
29

Parecer Ministério da Justiça. Réus Moisés e Ignácio. Maço $5 \mathrm{H}-55, \mathrm{GIFI}, \mathrm{AN}$.
Ver anotação a respeito do decreto no parecer do Ministério da Justiça. Maço 5 H-55, GIFI, AN.
Mais do que considerações a respeito da qualidade das provas e da atuação dos réus nos crimes (que não deixavam de ser tomadas em consideração pelos funcionários do Ministério da Justiça), pesavam considerações sobre a "justiça e conveniências sociais". No caso especifico dos réus de Nazareth, especificamente estava em jogo a libertação de escravos que haviam sido condenados pelo assassinato de seu senhor. 0 parecer do diretor geral reconhecia, contudo, que terminada a escravidão, não haveria mais motivos (ou mesmo meios) de segurar a pressão exercida a favor do perdão ou revisão das penas dos réus condenados. É certo que este parecer não defendeu uma revisão ampla das penas de todos os réus escravos, limitando-se a comentar o caso de Nazareth. Contudo, o argumento de que o "desespero" perante a "crueldade do senhor" havia levado os réus ao crime poderia se encaixar perfeitamente em diversas outras situações. Assim, a cada pedido de graça endereçado ao Poder Moderador reforçava-se o coro pela revisão das penas dos cativos, sendo que pareceres como o do diretor geral indicavam que tal caminho se tornava cada vez mais possivel de ser trilhado pelo governo imperial.

A documentação a respeito dos réus Moisés e Inácio subiu, então, para a decisão de Dom Pedro II. Não sei se chegaram às mãos do monarca antes de sua partida para a terceira viagem à Europa, iniciada em 30 de junho de 1887. Também não foi possivel identificar se o Imperador deixou alguma instrução para a Regente Princesa Isabel, a quem cabia, durante sua ausência, despachar os pedidos de graça. Fato é que em 29 de março de 1888, antes mesmo que fosse oficialmente extinta a escravidão no Brasil, Isabel mandou expedir um decreto perdoando os réus Moisés e Inácio da pena de galés perpétuas. ${ }^{30}$ É possivel que os argumentos do diretor geral, juntamente com a percepção de que escravidão não se sustentaria por muito tempo, tenham colaborado decisivamente para a atitude de Isabel. Para aqueles dois cativos de Nazareth, que cumpriram pena por mais de 20 anos, a liberdade finalmente se transformava em realidade. Não eram mais escravos nem prisioneiros. Estavam livres, enfim.

A notícia da liberdade de Inácio e Moisés alcançou rapidamente os ouvidos dos demais cativos que ainda cumpriam pena em Fernando de Noronha pelo assassinato de Joaquim Porfírio de Sousa (e certamente dos demais presos). Assim, em 24 de abril de 1888, pouco mais de 20 dias depois que foi expedido o decreto libertando Moisés e Inácio, Bráulio e Benjamin despacharam um pedido de graça à princesa Isabel, solicitando o perdão de suas penas. Faziam referência, é claro, ao perdão da pena de seus parceiros, que haviam sido condenados juntamente com eles pelo crime de assassinato de Joaquim Porfírio de Sousa. A expectativa da liberdade transparecia na narrativa desses pedidos de graça, escritos por Liberalino Rodrigues Machado. Transcrevo a carta de Bráulio a fim de que se possa conhecer um pouco mais do próprio documento.

\section{Senhora!}

Súplice perante os degraus do Augusto Trono de Vossa Majestade Imperial, prostra-se o infeliz Bráulio escravo dos herdeiros de Joaquim Porfirio de Souza, implorando o perdão. Sentenciado pelo Júri da Cidade de Nazareth (Bahia) em 19 de Março de 1864 pelo crime de homicídio, e remetido para este Presídio a 17 de Dezembro de 1868. A inata clemência e Magnanimidade de Vossa Majestade Imperial vem humilde pedir 
a graça do perdão na esperança de que os atos de Justiça, e equitativos sempre se apoderam do religioso coração de Vossa Majestade Imperial. 0 impetrante tem em vista o Decreto de 29 de Março do Corrente ano, com que Vossa Majestade Imperial houve por bem perdoar a seus co-réus por assim terem pedido perdão; deixando de serem os que não pediram graça; motivo que o Suplicante animado vem pedir a Vossa Majestade Imperial que Ihe contemple com a graça do perdão no dia 7 de Setembro, dia em que o Império de Santa Cruz muito se ufana de ter quebrado os ferros do jugo da escravidão = Independência ou Morte! A exposição que o Suplicante passa a fazer a Vossa Majestade Imperial é que há longos anos (20) sofre os rigores do cárcere resignado e arrependido assim como seus co-réus que foram ultimamente agraciados; e portanto, pede e espera o perdão pelo amor de Deus. E Pela graça que o Suplicante ora pede, não cessará de rogar a Deus que conceda a Imperial família paz e prolongados anos de vida a Vossa Majestade Imperial.

\section{E Receberá Mercê}

Presídio de Fernando de Noronha, 24 de Abril de 1888.

A rogo do Suplicante

Liberalino Rodrigues Machado ${ }^{31}$

A resposta da princesa Isabel veio com o decreto de 13 de setembro de 1888, libertando também Benjamin e Bráulio da pena de galés que cumpriam no presídio de Fernando de Noronha. Não sei qual destino tomaram os quatro réus depois de serem libertados das correntes das galés. Talvez tenham permanecido em Pernambuco, província a que estava ligado o Presídio de Fernando de Noronha. Ou talvez tenham retornado à Bahia, para tentar reencontrar os que ficaram para trás, naquele já distante ano de 1867. 0 certo é que passaram a enfrentar os desafios que Ihe impunham a vida sem

Pedido de perdão de Bráulio, Maço 5 H-55, GIFI, AN. o peso do chicote ou das correntes das galés. Com relação ao réu João, que também havia sido condenado junto com os demais pelo assassinato de Joaquim Porfírio de Sousa e fora enviado para Fernando de Noronha, não encontrei nenhum pedido de graça em seu nome dirigido ao Poder Moderador. É possível que nunca tenha mandado esse tipo de carta ao monarca, tendo talvez falecido na própria prisão. João era o mais velho de todos os réus daquele caso: tinha no momento do crime 45 anos. Dessa forma, pode ser que não houvesse tido forças suficientes para aguardar mais de duas décadas até que o perdão viesse. Ficara em Fernando de Noronha.

0 caso dos réus de Nazareth da Bahia se assemelha ao de muitos outros escravos, que da prisão enviaram e reenviaram pedidos de graça ao Poder Moderador até alcançar a liberdade. Suas cartas pressionavam o monarca para a revisão, ou perdão completo, das penas que cumpriam, reforçando as críticas ao sistema penal. Outro exemplo de persistência, que resultou na liberdade, vem do escravo Inácio. Em outubro de 1875, o júri de Nova Friburgo, Rio de Janeiro, condenou Inácio a pena de galés perpétuas pelo crime de assassinato. ${ }^{32} \mathrm{Em}$ depoimento a policia e aos magistrados, Inácio confessou que no dia 9 de julho de 1875 matou o feitor da fazenda em que morava, Joaquim Pedroso. Ele destacou que ao se dirigir à roça, para se juntar a um grupo de escravos na colheita do café, o feitor o encontrou no meio do caminho e o repreendeu com uma "chicotada e algumas relhadas", por estar atrasado para o trabalho. Ao longo do processo, Inácio destacou que tentou justificar sua demora para Joaquim Pedroso, contando que o seu senhor o mandara varrer o terreiro antes de seguir para a roça. 0 feitor, contudo, não 
32

Caso do réu Ignácio. Maço 5H-109, Ministério da Justiça, GIFI, AN.

Pedido de perdão do réu Ignácio. 9 de março de 1878. Maço 5H-109, Ministério da Justiça, GIFI, AN.

34

Parecer Ministério da Justiça. Réu Ignácio. Maço 5H-109, Ministério da Justiça, GIFI, AN.

35

Pedido de perdão de Ignácio. 2 de dezembro de 1880. Maço 5H-109, Ministério da Justiça, GIFI, AN. teria dado crédito à sua explicação e continuou a Ihe castigar. Insultado, Inácio sacou uma faca que trazia junto a cintura e matou Joaquim Pedroso. Logo em seguida, foi capturado por seus parceiros, que o viram correndo com a faca ensanguentada na mão. Inácio foi preso e pronunciado pelo artigo primeiro da lei de 10 de junho de 1835. Durante o julgamento, o conselho de jurados entendeu que não havia outras provas do crime além da confissão de Inácio, e recomendou a imposição da pena de galés perpétuas. 0 escravo foi transferido da cadeia de Nova Friburgo, onde estava preso, para a Casa de Detenção da província do Rio de Janeiro, em Niterói. Começava ali sua luta pela libertação.

A primeira carta que Inácio escreveu foi da Casa de Detenção, de Niterói, para o Poder Moderador, com data de 9 de março de $1878 .{ }^{33} \mathrm{Um}$ dos argumentos centrais evocados pelo réu para pedir a revisão ou perdão de sua pena, com menos de três anos de prisão, ligava-se ao fato de estar doente, internado na nona enfermaria, anexa do Hospital de São João Batista. Para comprovar a sua situação de enfermo, Inácio enviou o parecer do médico da prisão, João Francisco de Souza, que atestou que ele sofria "das consequências de um anus artificial na região hipogástrica", desde que chegara à prisão. Nesse pedido de graça, alegou que sua ação na morte do feitor nasceu de uma atitude "não voluntária" diante das agressões que recebeu. Joaquim de Oliveira e Silva escreveu a carta para Inácio, de dentro do hospital de São João Batista. Na avaliação do Ministério da Justiça, porém, o pedido de graça de Inácio deveria ser recusado. Próspero Jeová, responsável pela parecer do caso, nem mesmo considerou a condição de enfermo do réu. Concentrou as suas considerações na alegação de que o crime foi cometido involuntariamente. Próspero Jeová destacou que tal argumento não constituia elemento suficiente para garantir ao réu o perdão imperial, já que o "direito de castigar estava garantido pelo artigo 14, parágrafo 6". Victorino de Barros (também membro da terceira seção do Ministério da Justiça) e o diretor geral, Figueiredo José, concordaram com o parecer. 0 Imperador também não se comoveu com os argumentos e a doença de Ignácio, mantendo-o na prisão. ${ }^{34}$

0 condenado, contudo, não desistiu de seu intento. Em 2 de dezembro de 1880 , data do nascimento de Dom Pedro II, voltou a carga. ${ }^{35}$ Destacou que o crime pelo qual foi condenado não havia sido testemunhado por ninguém (o que de fato foi reconhecido pelo júri de Nova Friburgo em 1875) e que sua reação diante do feitor tinha como objetivo "defender" sua própria "vida". Para reforçar a tese de que agiu em legitima defesa, Inácio descreveu a si mesmo como sendo "aleijado", ao tempo em que caracterizou o feitor como um "homem robusto". 0 réu pedia, dessa forma, com base no artigo 18 do Código Criminal, parágrafo terceiro ("circunstância atenuante: ter 0 delinquente cometido o crime em defesa própria"), que tivesse a sua pena reduzida ou perdoada. Como continuava internado na enfermaria anexa do hospital São João Batista em Niterói, mais uma vez anexou um atestado médico que certificava a sua condição. A carta de perdão foi escrita por Eduardo de Oliveira Porto. Os funcionários do Ministério da Justiça novamente desconsideraram o fato de o réu se encontrar doente e centraram as suas análises no argumento de "legitima defesa". Próspero Jeová foi o responsável pelo parecer inicial do caso. Destacou que o feitor tinha por lei o direito a castigar o escravo e que, portanto, não se justificava a aplicação do artigo 18, parágrafo terceiro, como elemento atenuante. 0 mesmo concluíram os demais funcionários do Ministério da Justiça, seguindo a decisão de Prós- 
36

Parecer Ministério da Justiça. Réu Ignácio. Maço 5H-109, Ministério da Justiça, GIFI, AN.

37

Parecer Ministério da Justiça. Réu Ignácio. Maço 5H-109, Ministério da Justiça, GIFI, AN.

38

Parecer Ministério da Justiça. Réu Ignácio. Maço 5H-109, Ministério da Justiça, GIFI, AN.

39

Pedido de perdão do réu Ignácio. 10 de junho de 1885. Maço 5H-109, Ministério da Justiça, GIFI, AN. pero Jeová. Também o monarca não se mostrou disposto a ceder às súplicas do condenado. ${ }^{36}$

Em 26 de junho de 1881, Inácio insistiu mais uma vez em conseguir uma revisão ou perdão de sua pena. Não se conformava com os indeferimentos anteriores (trata-se então da sua terceira carta). ${ }^{37}$ Os argumentos utilizados foram os mesmos dos outros pedidos de graça: a doença (enfatizou nesse momento que nem mesmo conseguia levantar-se da cama) e o fato de ter agido em defesa própria, quando ocorreu o crime. A resposta do Ministério da Justiça demorou quase um ano para ser expedida. Apenas em julho de 1882 o caso recebeu um parecer. Talvez os homens da burocracia imperial buscassem acalmar o furor com que Inácio mandava os seus pedidos de graça ao monarca em busca de sua libertação. Destacou J. Moller, funcionário da terceira seção do Ministério da Justiça, que a alegação de Inácio - de que nem mesmo se levantava da cama - devia ser embasada em "mínima prova", o que não se via na documentação. Com relação a questão de ter agido em legítima defesa, J. Moller destacou que tal argumento era "banal e frivolo", não tendo o feitor intenção alguma de matá-lo no momento em que aplicou castigos com o chicote que tinha em mãos. De fato, o tom do parecer de J. Moller era mais ríspido do que aqueles apresentados por Próspero Jeová (apesar de ambos indeferirem os pedidos de graça). J Moller destacou, por exemplo, que em sua opinião o júri de Nova Friburgo agiu erroneamente ao considerar que existiam outras provas além da confissão do réu, pois "coincidindo as circunstâncias do crime" com o depoimento de Inácio, formava-se um conjunto de elementos suficientes para a condenação capital (resgatava assim J. Moller uma das interpretações mais defendidas por José de Alencar enquanto parecerista do Ministério da Justiça, na década de 1860). Os demais funcionários do Ministério e o monarca seguiram o parecer de J. Moller. ${ }^{38}$

Diante das três negativas para seus pedidos de graça, Inácio diminuiu a frequência com que recorria ao Poder Moderador (enviou pedidos quase que anuais desde 1878), mas não desistiu. Assim, em 10 de junho de 1885, o escravo votou à tona, e tentou reverter a sua situação de prisioneiro. ${ }^{39}$ Os dois argumentos, já apresentados anteriormente, reaparecem: a doença e 0 assassinato do feitor como ato de legítima defesa. Porém, um elemento novo foi trazido para a discussão. Inácio alegou que o feitor tinha "interesse" em sua mulher e chegou a dizer que, por ser ele um escravo "doente", não conseguiria "sustentá-la" por muitos anos. Destacou, então, que tendo a sua "honra abusada" com essas palavras, respondeu prontamente ao feitor, que passou a ter "raiva" dele e a "jurar vingança". Buscava, assim, dar mais sustentação à alegação de que o assassinato do feitor tinha ocorrido em legítima defesa, pois já havia até mesmo uma promessa de morte contra ele.

Esse documento tinha ainda outra novidade em relação aos demais, contou o escravo que falara de seu caso pessoalmente para o Imperador, quando este visitou o hospital de São João Batista, em Niterói. 0 autor dessa carta do ano de 1885 foi o mesmo individuo que já havia ajudado Inácio com a petição de graça em 1880, Eduardo de Oliveira Porto. Mais uma vez, porém, as expectativas de liberdade de Inácio foram barradas no parecer assinado por J. Moller, que justificava da seguinte forma a negativa do perdão: "são fúteis as alegações e já se acham refutadas nos trabalhos anteriores e por isso na falta de fato ou circunstâncias relevante que modifique a carência de merecimento da suplica, parece que o peticionário continua a desmerecer a clemência Imperial". 0 mesmo parecer foi assinado por Victorino de 
40

Parecer Ministério da Justiça. Réu Ignácio. Maço 5H-109, Ministério da Justiça, GIFI, AN.

41

Pedido de perdão de Ignácio. 23 de agosto de 1887. Maço 5H-109, Ministério da Justiça, GIFI, AN.
Barros e Figueiredo José. Também o imperador não Ihe favoreceu com uma nova graça. ${ }^{40}$

Mas, se até aquele momento Inácio não conseguia romper as grades da prisão com seus repetidos pedidos ao monarca, a carta enviada em 23 de agosto de 1887 teve destino diferente das demais (representava então a quinta tentativa). ${ }^{41} 0$ documento em nada se distanciava dos argumentos já mencionados anteriormente, apenas mais alguns detalhes foram dados em relação a sua doença, que seria consequência de uma "lesão orgânica do coração e um anus artificial" na barriga que o forçava a viver deitado em uma cama. 0 documento, assinado pelo "advogado" Henrique Antão de Vasconcelos, evidenciava a luta de muitos bacharéis em direito em nome dos réus escravos, que se atribuiam a tarefa de tentar reverter as sentenças condenatórias perante o Poder Moderador. A análise desse pedido, assim como o de 1881, demorou quase um ano para ocorrer (veio a acontecer apenas em 26 de maio de 1888). Se naquele momento sugeri que a demora na tramitação do pedido de graça talvez fosse decorrente de uma atuação deliberada dos funcionários do Ministério da Justiça para diminuir a frequência com que Inácio mandava suas cartas, no caso da solicitação de 1887 os motivos podem ter sido outros. É possível que, nesse período, estivesse em discussão a possibilidade de se alterar a própria maneira de analisar os pedidos de graça, tendo em vista a recorrência com que eram enviados e as expectativas crescentes geradas pelo processo abolicionista.

Fato é que os mesmos argumentos, que Inácio insistia em suas petições desde 1878, e que até então eram tratados como "fúteis", "frívolos" e "banais", foram então aceitos. 0 parecerista era o mesmo Jorge Moller. Segundo destacou em seu parecer, "o réu já estava preso há 12 anos e 7 meses, o que seria tempo suficiente para ver cumprida a sanção penal imposta pelo artigo 193 [assassinato sem agravantes] do Código Criminal", caso tivesse sido Inácio julgado pelo Código Criminal e não pela lei de 10 de junho de 1835. Além disso, destacou Moller, o réu apresentava "moléstias incuráveis", que o "obrigam a aguardar constantemente o leito". Assim, concluiu o parecerista, "combinadas estas duas circunstâncias podem influir para que o suplicante seja reputado merecedor do perdão durante a próxima futura Semana Santa". 0 diretor geral, José Julio de Albuquerque Barros, também reconheceu que o réu merecia uma revisão de sua pena, contudo, em tom mais cauteloso que Jorge Moller, recomendou que Inácio tivesse sua sentença comutada para 20 anos de galés, discordando da sugestão de perdão imediato. $^{42}$

Os pareceres de J. Moller e José Júlio de Albuquerque Barros, apesar de divergentes quanto ao momento em que o réu deveria receber o perdão, nos ajudam a entender os próprios parâmetros adotados pelo Ministério da Justiça para avaliar os pedidos de graça de réus escravos naquele momento. De fato, o processo geral de revisão das penas dos cativos condenados pela lei de 10 de junho de 1835, que tomou conta da burocracia imperial em 1888, adotou como critério norteador as próprias disposições presentes no Código Criminal. Isto é, os funcionários do Ministério da Justiça reavaliaram os processos-crime a partir das penalidades previstas pela lei comum. Assim, concluiu J. Moller que o caso de Inácio poderia ser incluído no grau médio do artigo 193 do Código Criminal (12 anos de prisão com trabalho), enquanto que o diretor geral entendeu que se tratava de um caso que se adequava ao grau mínimo do artigo 192 (20 anos de prisão com trabalho). Foi também baseado nos mesmos princípios, ao que tundo indica, que o diretor geral,
Parecer Ministério da Justiça. Réu Ignácio. Maço 5H-109, Ministério da Justiça, GIFI, AN. 
43

Decreto de perdão, Maço 5H-109, Ministério da Justiça, GIFI, AN.

44

Caso da ré Josefa. Pacote 3, Caixa 772, Ministério da Justiça, AN.

45

Pedido de perdão de Josefa. 1 de novembro de 1875. Pacote 3, Caixa 772, Ministério da Justiça, AN.
José Júlio de Albuquerque Barros, sugeriu, em junho de 1887, que os réus de Nazareth podiam ser libertados depois de acabada a escravidão. É possivel que ele considerasse que aquele caso também se enquadrava no grau mínimo do artigo 192, e que completando os réus 20 anos de galés em 1887, a liberdade para eles podia vir assim que acabasse a escravidão. De qualquer forma, com relação a Inácio, o diretor geral propunha que o mesmo cumprisse mais 8 anos de prisão até atingir os 20 anos estipulados pelo artigo 192. Para felicidade de condenado, contudo, ficou o Imperador com a sugestão de Jorge Moller, talvez, levando em consideração a sua condição enferma. Em 19 de abril de 1889, Sexta-feira da Paixão, o Imperador mandou expedir um decreto libertando Inácio da prisão. ${ }^{43}$

Outro caso é o de uma escrava de vila de Piratinim, Rio Grande do Sul, também chamada Josefa e que conseguiu a revisão da pena em $1888,{ }^{44}$ No dia 2 de março de 1851, aproveitou o fato de seu senhor não estar em casa para matar afogada Florisbela Silveira da Rosa e seu filho Manoel. 0 motivo para o crime ligava-se ao "ciúme" e a "raiva" que a escrava tinha de sua senhora pelo fato de ter sido ela, escrava, "amancebada" com seu senhor, antes de ele se casar com Florisbela Silveira da Rosa. Josefa confessou o crime e acabou condenada a morte, segundo o artigo primeiro da lei de 10 de junho de 1835. 0 seu caso subiu ao Poder Moderador, que comutou a sentença de morte em prisão perpétua com trabalho (a ser cumprida no presídio de Porto Alegre).

Diferentemente dos casos que analisamos até agora, Josefa enviara apenas uma carta ao Poder Moderador, depois da comutação da pena de morte em prisão perpétua. Essa carta é de 1 de novembro de 1875, escrita por Porfírio Barboza e dirigida à princesa Isabel. ${ }^{45}$ Voltavam-se os réus escravos à princesa quando ela estava no comando do Império e do Poder Moderador, ou seja, nos momentos em que Dom Pedro II estava em viagem fora do Brasil. Porém, este não era o caso naquela data. 0 que explica, de fato, o direcionamento da carta à princesa foi mesmo uma estratégia da ré (e seu defensor) de tentar criar algum tipo de identidade e, consequentemente, misericórdia, por conta da condição feminina de ambas. A carta, como veremos abaixo, destaca a "triste, tristíssima" situação a que estava submetida a "mulher escrava". Esse documento apresenta ainda outra particularidade em relação aos demais: ele tem 10 páginas ao todo, um tamanho pouco comum em minha amostra. A sua leitura nos mostra o quanto Porfírio Barbosa estava engajado na luta pela liberdade daquela escrava. Boa parte do pedido de graça se destinava a apresentar diversos casos de homicidas ou de personagens da história que cometeram crimes e que acabaram perdoados, começando por Caim e Abel, passando por Moisés, David até chegar a Manoel José de Sepúlveda (ex-presidente da província do Rio Grande do Sul), Marquês de Pombal, José Rezende da Costa, padre Manoel Rodrigues da Costa, Marquês e Marquesa de Távora. Na carta, a autoria do crime de Josefa não é negado, mas se responsabiliza as próprias condições do cativeiro para o fato. Vale a pena acompanhar o texto.

Eu sei que a sociedade zomba da vitima para proclamar a vitória do algoz; mas [?], muitas vezes, destrói-se o jus do oprimido para dar força ao opressor. Se eu houvera nascido gozando os doces eflúvios da abençoada lei de 28 de setembro de 1871, não estaria no cárcere há 24 anos, expiando o crime de homicídio! A escravidão, nessa livre terra americana, tem proporcionado mil ocasiões para tais acometimentos, 
46

Pedido de perdão de Josefa. 1 de novembro de 1875. Pacote 3, Caixa 772, Ministério da Justiça, AN. sim, matei, matei sufocando mãe e filho dentro de um arroio em que lavavam, não neguei o meu crime (crime horrendo, porém, filho do momento em que o coração humano se deixa levar pela irreflexão), mas as circunstâncias filhas dessa mesma irreflexão ninguém as sabe, porque ninguém pode mostrar no foro da consciência alheia, só um as podia saber e delas me recordo, como se ainda os negros grilhões do cativeiro me estivessem torturando os pulsos. Cometi o crime em lugar ermo e sem que uma só pessoa o presenciasse, poderia negá-lo, não o fiz, porque esse crime não foi perpetrado intencionalmente, embora no processo incluso algum dissesse que nele houve premeditação, mas isso é pela razão já mencionada - enfraquecer o oprimido para fortalecer o opressor [...] Nessa época fatal da minha vida, esqueci-me de que uma mulher escrava era uma coisa e não uma pessoa e que, portanto, devia dobrar-se a todas as disposições daqueles sob cujo capricho vivia! Bárbara lei do meu fado! [...] Senhora, eu confessei o crime, é verdade, mas os meios empregados para essa confissão, Senhora, foram as torturas empregadas outrora para extorquir da vítima os meios para a sua condenação, mas isso, Senhora, era naquele tempo em que só podia haver acusação e não defesa. É verdade! Algemaram-me e, metida em um tronco, faziam-me as perguntas coniventes ao caso e ai! de mim, Senhora, que eu não respondesse afirmando o que me perguntavam ou voluntária, mas não livremente, não dissesse o insinuavam! Acorrentada, como consta no meu processo, e sem que ainda se tivesse conhecimento de ter ou não ter eu cometido crime algum, e antes de culpada [sic] formada, açoitaram-me sem piedade. E não admira que eu tivesse satisfeito os desejos dos irmãos da minha finada senhora, Dona Florisbela, porque outras pessoas, com pleno conhecimento do seu direito, satisfazem as perguntas que Ihe são feitas pelas torturas que sofrem! Quanto mais eu, Senhora, mesquinha escrava, a quem faltavam os menores conhecimentos da forma de direito e da razão; e a quem um senhor, esquecido da fidelidade que devia guardar ao tálamo conjugal, exercia meios coercivos para conseguir seus fins. Triste, tristíssima a condição da mulher escrava em $1851 ! ! !^{46}$

0 documento é um verdadeiro manifesto contra a escravidão e sua capacidade de transformar "gente" em "coisas". Sujeitos aos "caprichos" de seus senhores, os escravos eram açoitados e torturados. Os seus direitos eram negados. Josefa lamentava não ter nascido depois da lei de 28 de setembro de 1871, pois se assim fosse estaria livre da prisão. Buscava ainda ligar o crime que cometera às próprias condições do cativeiro e destacava as severas condições que eram impostas pela justiça criminal aos escravos (fosse livre não estaria mais presa). 0 documento apelava também para as particularidades de sua condição feminina, que a fez passar por situações a que não estavam sujeitos os homens diante de um senhor, "esquecido da fidelidade que devia guardar ao tálamo conjugal" e capaz de exercer "meios coercitivos para conseguir seus fins". A carta, em suma, era um lamento indignado das condições a que estavam sujeitos os escravos no cativeiro e ainda abordava a severidade da justiça imperial. Assim, restava somente apelar para a misericórdia do rei.

Ao chegar ao Ministério da Justiça, o pedido de graça de Josefa demorou mais de dois anos até que fosse analisado. Não sei exatamente 0 produziu tão longa demora. De qualquer forma, o parecer dos funcionários do rei foi negativo para as aspirações de liberdade de Josefa. Sobre o caso, Próspero Jeová escreveu: "a ferocidade da peticionária, revelada nesses dois horriveis assassinatos, de sua inofensiva senhora e dessa inocente vítima de seu amor materno, levou a seção de Justiça do Conselho de Estado, consultada sobre o primeiro recurso de graça, a pronunciar-se pela execução da pena capital, que foi comutada pelo Poder Moderador atendendo, ao que parece, às circunstâncias de sua menoridade e de não haver outra prova além de sua confissão. Depois desse indulto [...] não parece que esteja no caso de 
Parecer do Ministério da Justiça. Pacote 3, Caixa 772, Ministério da Justiça, AN.

48

Parecer do Ministério da Justiça. 1888. Pacote 3, Caixa 772, Ministério da Justiça, AN.

49

Foram identificados 37 escravos que tiveram seus processos incluídos no processo de revisão em 1888. Desses 37 que tiveram o caso revisado, 19 alcançaram o perdão do restante da pena, 5 tiveram a pena convertida em 20 anos de prisão com trabalho e 13 não foram considerados dignos de receber a graça Imperial. ser atendida". Seguiram sua opinião, Almeida França, outro funcionário do Ministério da Justiça, e o diretor geral, Figueiredo José. Também a princesa Isabel e o monarca não se comoveram com seu pedido. ${ }^{47}$

Diversamente da maioria dos casos que pesquisei, Josefa mandou apenas uma carta ao Poder Moderador solicitando o perdão de sua pena. Não sei se desanimada com a negativa dada à sua solicitação, ou se em dificuldades em encontrar um defensor que the ajudasse a enviar mais cartas ao monarca. 0 fato é que Josefa teve que esperar por mais de uma década, depois daquele pedido de 1875, para que finalmente pudesse sair da prisão. Em 1888, o seu caso foi analisado no processo de reavaliação da pena dos réus condenados pela lei de 10 de junho de 1835, conseguindo um parecer positivo do Ministério da Justiça, que se converteu em seu perdão. A decisão dos funcionários do Império, dessa vez, levou em consideração a "menoridade da ré" no momento do crime e a inexistência de "outras provas além de sua confissão", que somados ainda aos "30 anos de cumprimento da pena" favoreciam o "perdão" imperial. 0 decreto de sua libertação da cadeia foi de 13 de maio de $1889 .{ }^{48}$

0 caso de Josefa se junta ao grande número de réus escravos que no ano de 1888 foram beneficiados pelo processo de revisão de penas instituído pelo governo imperial. Apenas para se ter uma ideia de como tal iniciativa produziu um número enorme de perdoados, apresento alguns dados que puderam ser levantados a partir da minha amostra de casos colhidos entre a documentação do Ministério da Justiça e do Conselho de Estado, no Arquivo Nacional. Assim, de todos os réus escravos que tiveram suas penas revisadas em 1888 (e que pude identificar a documentação), cerca de 50\% deles conseguiram o perdão total da sentença. Outros 14\% receberam uma redução da pena para 20 anos de prisão com trabalho. Enquanto os demais, 36\% não foram considerados dignos de receber a graça imperial. ${ }^{49} \mathrm{~A}$ grande maioria dos réus que foram perdoados havia cometido crimes na década de 1860 ou em períodos anteriores, isto é, estava há mais de 20 anos cumprindo sentença quando se iniciou o processo de revisão das penas. Já os escravos que tiveram a pena convertida para 20 anos de prisão com trabalho praticaram crimes na década de 1870, ou mesmo nos anos 1880. Assim, o que parece ter sido o mais comum naquele processo de revisão foi a conversão da pena dos réus condenados pela lei de 10 de junho de 1835 para o grau mínimo do artigo 192 (20 anos de prisão com trabalho), comutando a sentença de quem ainda não havia chegado às duas décadas de prisão e libertando quem já havia alcançado ou ultrapassado tal tempo.

A data escolhida para libertar os perdoados pelo processo de revisão de sentença foi 13 de maio de 1889. De fato, com tal iniciativa o Imperador rompia com a tradição de privilegiar a Sexta-feira da Paixão (que naquele ano caiu em 19 de abril) como data predileta para expedir os perdões reais. Reforçava-se, assim, os significados do 13 de maio para a população liberta no Brasil. Se em 1888 a escravidão ficou para trás, e com ela as distinções fundamentais entre réus livres e escravos perante a Justiça criminal, em 1889 os direitos recém conquistados de igualdade jurídica tornavam-se retroativos aos sentenciados pela lei de 10 de junho de 1835, que ainda cumpriam pena. Tratava-se de mais uma vitória fundamental para a comunidade de libertos no Brasil. A circular enviada aos presidentes de província, pedindo a remessa dos casos de réus escravos condenados pela lei de 10 de junho de 1835, que eventualmente ainda não houvesse chegado ao conhecimento do Poder Moderador, justificava a medida da seguinte maneira: 
50

RIBEIRO, João Luiz. No meio das galinhas... Op.cit., p. 311 , nota 21 .
A lei de 13 de maio de 1888, declarando extinta a escravidão no Brasil, virtualmente revogou a de 10 de junho de 1835, fazendo cessar sua razão de ser e os motivos especiais de segurança pública e individual, originados da condição servil, que determinavam suas disposições excepcionais relativamente aos delitos nela previstos, na verificação da culpa, na penalidade, no julgamento e nos recursos, colocando os réus fora do direito comum, não só quanto aos elementos morais da responsabilidade criminal e garantias de julgamento, como no tocante 'à natureza e grau do castigo, sem outro apelo senão à atribuição constitucional do poder moderador de perdoar ou moderar as penas impostas aos condenados, conforme os preceitos de justiça e humanidade e os interesses gerais do Estado; o que tudo ponderado e atendendo a que suprimida a condição servil, não é justo que subsistam os seus efeitos nas penas a que estão submetidos muitos sentenciados, e cujo rigor a dita lei de 13 de maio tornou-se desnecessário e inútil em todos os casos em que só o justificava a permanência do fato da escravidão. Houve por bem Sua Majestade o Imperador ordenar que subam de nova à sua Augusta Presença todas as petições de graça dos réus condenados sob o regime e segundo as prescrições da lei de 10 de junho de 1835 [...] outrossim que seja recomendado a todas as presidências, como recomendo, a pronta remessa das copias dos processos respectivos, de que ainda não houver traslado na secretaria de Estado. ${ }^{50}$

É certo que medidas como essa adotada pelo Imperador despertaram críticas a respeito dos riscos que causavam à segurança pública. Rui Barbosa foi, na época, um dos principais opositores do processo de revisão das penas dos réus condenados, destacando que o monarca "sacrificava a segurança pública em nome do sentimentalismo". Fato é que tais críticas não conseguiram, contudo, barrar a iniciativa de festejar o 13 de maio de 1889 com a libertação dos condenados pela lei de 10 de junho de 1835. Uma nova onda de libertados tomavam as ruas do país, eram os egressos das grades e correntes das prisões.

\section{Conclusão}

As frequentes respostas negativas que os réus escravos receberam para seus pedidos de graça, nas décadas de 1870 e 1880, reforçam a constatação de que apenas um número bastante reduzido dos suplicantes conseguiu o perdão da pena antes da abolição em 1888. Conforme as estimativas apresentadas no início deste artigo, a quantidade de réus contemplados pela decisão do monarca naqueles anos não ultrapassaria a 6 casos anuais. Somente na véspera da abolição, quando os acontecimentos políticos e socais indicavam o fim próximo do escravismo no pais, é que parece ter crescido a aceitação dos pedidos de graça a exemplo dos casos de Inácio e Moisés, presos em Fernando de Noronha e libertados em março de 1888.

A parcimônia do Estado imperial na concessão do perdão não significou, contudo, que os pedidos de graça tenham desempenhado um papel destituído de consequências políticas. Em primeiro lugar, é importante destacar que a própria decisão de 17 de outubro de 1872 favoreceu um aumento dos pedidos de graça enviados ao monarca. É o que indica, pelo menos, a pesquisa feita junto aos fundos do Ministério da Justiça e do Conselho de Estado, no Arquivo Nacional, que mostra como as décadas de 1870 e 1880 representaram justamente os anos de maior concentração de cartas de perdão nesse acervo. Mesmo sendo uma prática que remontava ao período colonial, foi apenas nos anos finais do Império que o envio de pedidos de perdão ao 
51

Sobre as críticas ao sistema penal do Estado Imperial, cf. PIROLA, Ricardo F. Op. Cit., p. 143272.

52

Caso dos réus Bráulio, Benjamin, Moisés, Ignácio, Maço $5 \mathrm{H}-55$, GIFI, AN. monarca parece ter atingido o seu apogeu. 0 contexto de crescimento da campanha abolicionista e a decisão de 1872, de libertar os perdoados do domínio senhorial, ajudam a explicar essa grande concentração de cartas de perdão nos anos 70 e 80 do século XIX. Tal medida reforçava a percepção nos cativos e líderes abolicionistas: a possibilidade de fazer das instituições do Estado imperial uma arena de luta pela liberdade.

Em segundo lugar, as insistentes cartas dos réus escravos se juntavam ainda a uma luta mais ampla travada em tribunais, no Ministério da Justiça, no Conselho de Estado e na imprensa contra as severas penas previstas pela legislação criminal para os crimes cometidos por escravos. 0 argumento de que os cativos se encontravam longos anos presos, frequentemente utilizado nessas cartas de perdão, fazia coro com as críticas ao sistema penal do Império acerca da grande discrepância entre as punições previstas para livres e para escravos, sendo sempre mais duras para os últimos. ${ }^{51} \mathrm{Em}$ parecer sobre um pedido de graça de 1865, por exemplo, o presidente da Relação da Bahia chegou a propor a comutação das penas capitais de 5 réus escravos envolvidos no assassinato do seu senhor para punições semelhantes a que seriam aplicadas aos homens livres. ${ }^{52}$ Naquele momento seu parecer foi rejeitado. Contudo, o presidente da Relação não estava só na luta por um sistema penal menos discrepante no que se referia às punições destinadas a livres e escravos. Outros tantos magistrados, advogados, curadores, abolicionistas defendiam as mesmas posições nos tribunais, imprensa e encontros abolicionistas.

Assim, mesmo o monarca não tendo cedido aos pedidos para o perdão total das penas até à véspera da abolição, a pressão exercida por escravos e por seus curadores não parece ter sido em vão. A decisão imperial de rever as penas dos réus condenados durante a vigência da escravidão remetia a essa longa campanha de críticas ao sistema penal do Império, representada tanto pelos discursos, pareceres e decisões tomadas no âmbito da burocracia imperial, quanto pelos pedidos de perdão de réus escravos. A libertação pode não ter vindo de imediato para a maioria dos cativos que enviaram suas cartas de perdão ao monarca, mas se concretizou para grande parte deles em 13 de maio de 1889.

\section{Fontes Documentais}

CAROATÁ, José Prospero Jeová (organizador). Imperiais Resoluções tomadas sobre Consultas da Seção de Justiça do Conselho de Estado desde o ano de 1842 até hoje. Volume 2. Rio de Janeiro: B.L. Garnier Livreiro Editor, 1884.

NABUCO, Joaquim. Um estadista do Império: sua vida, suas opiniões, sua época. Volume 3. Rio de Janeiro: Garnier Livreiro e Editor, 1897.

\section{Bibliografia}

AZEVEDO, Elciene. 0 direito dos escravos: lutas jurídicas e abolicionismo na província de São Paulo. Campinas: Editora da Unicamp, 2010.

CHALHOUB, Sidney. Visões da liberdade: uma história das últimas décadas 
da escravidão na Corte. São Paulo: Companhia das Letras, 1990.

GERSON, Brasil. A escravidão no Império. Rio de Janeiro: Pallas, 1975.

NABUCO, Joaquim. Um estadista do Império: sua vida, suas opiniões, sua época. Volume 3. Rio de Janeiro: Garnier Livreiro e Editor, 1897.

PINAUD, João Luiz Duboc. Senhor, escravo e direito: interpretação semânticopolítica. In: ; ANDRADE, Carlos Otavio de \& NEME, Salete. Insurreição negra e justiça. Rio de Janeiro: Editora Expressão e Cultura, 1987.

PINAUD, João Luiz; ANDRADE, Carlos Otavio de; NEME, Salete. Insurreição negra e justiça. Rio de Janeiro: Editora Expressão e Cultura, 1987.

PIROLA, Ricardo F. Escravos e rebeldes nos tribunais do Império: uma história social da lei de 10 de junho de 1835. Rio de Janeiro: Arquivo Nacional, 2015.

RIBEIRO, João Luiz. No meio das galinhas, as baratas não têm razão: a lei de 10 de junho de 1835, os escravos e a pena de morte no Império do Brasil (1822-1889). Rio de Janeiro: Renovar, 2005.

SILVA, Maria Beatriz Nizza da (coord.). Cultura portuguesa na Terra de Santa Cruz. Lisboa, Estampa, 1995.

WO0D, Russell. Vassalo e soberano: apelos extrajudiciais de africanos e de indivíduos de origem africana na América portuguesa. In: SILVA, Maria Beatriz Nizza da (coord.). Cultura portuguesa na Terra de Santa Cruz, Lisboa, Estampa, 1995. 